\title{
Consumer perceptions of a perilous product: international tourism to South Africa
}

\author{
Mike Bendixen, Denis Cronson \& Russell Abratt* \\ Graduate School of Business Administration, University of the Witwatersrand, Johannesburg, P.O. Box 98. Wits. \\ 2050 Republic of South Africa \\ 2.9.11 Touisor \\ Received July 1996
}

\begin{abstract}
Tourism can make a significant contribution to the development of South Africa by providing employment. contributing to foreign exchange earnings and by increasing economic activity. The aim of this study was to establish current perceptions, attitudes and orientations of foreign tourists towards post-apartheid South Africa as a tourist destination. A sample of 250 tourists were interviewed at London's Heathrow Airport. The results show that the South African tourism industry is faced with a multidimensional problem. It is a good example of a perilous or high risk product. However, with sound market segmentation and targeting, and proper planning, South Africa can have a vibrant and sustainable tourism industry. A unique way of segmenting tourist markets is presented. Specific recommendations are discussed in detail, which could aid all those involved in marketing a high risk product.
\end{abstract}

\begin{abstract}
Toerisme kan 'n wesenlike bydrae lewer tot die ontwikkeling van Suid-Afrika deur die verskaffing van werk, verhoging in buitelandse valuta-verdienste en deur die toename in ekonomiese aktiwiteite. Die doel van dié studie was om huidige persepsies, houdings en oriëntasies van buitelandse toeriste teenoor Suid-Afrika as 'n toerisme-aantreklikheid in die postapartheidsera, vas te stel. Onderhoude is met 'n groep van 250 toeriste op Heathrow-lughawe in Londen gevoer. Die resultate toon dat die Suid-Afrikaanse toerisme-industrie 'n multidimensionele probleem in die gesig staar, en 'n goeie voorbeeld is van ' $n$ gevaarlike of hoë risiko-produk. Nietemin, met goeie marksegmentering, doelwitstelling en behoorlike beplanning kan Suid-Afrika 'n dinamiese en volgehoue toerisme-industrie daarstel. 'n Unieke metode van segmentering van toeristemarkte word aangebied. Spesifieke aanbevelings word in detail bespreek ten einde almal betrokke by die bemarking van 'n hoë risiko-produk te help.
\end{abstract}

*Author to whom correspondence should be addressed.

\section{Introduction}

Tourism is an integral industry in many developing countries, having the capacity to provide both substantial employment, a significant contribution to foreign exchange earnings and increased economic activity in general. International tourism in 1994 directly employed more than 127 million people and generated direct and indirect employment for more than 200 million people - or one of every nine workers world-wide (Gatty, 1993). The industry in South Africa is fourth in foreign exchange, at R10 billion, accounting just 3\% of gross national product (Caras, Saunders, Bird \& Kleynhans, 1993). The average annual growth rate of the global tourism industry over the past three decades has been $6 \%$ compared with a figure of only $2.5 \%$ for South Africa (Botha, 1993). In 1993, only 620000 overseas tourists visited South Africa, representing a mere $0.25 \%$ of the world's tourism market (Satour, 1993). In addition, South African tourism employs only one in every seventy workers (De Vaal, 1994).

South Africa is now a democratic country and is accepted by the community of nations. This emergence as a potential model of managed reform has captured the imagination of the governments of many nations and the keen interest of the world media. Given the importance of international tourism in bringing about economic, social and cultural advancement, the aim of this research was to establish current perceptions, attitudes and orientations of foreign tourists regarding postapartheid South Africa as a tourist destination. As South Africa has a high crime rate, where it is relatively unsafe for a tourist, it is a good example of a perilous, discretionary product. The aim is to test consumer perceptions of a very risky purchase decision.

\section{Literature review}

Tourism is not yet underpinned by a strong conceptual and theoretical base. Much of the published work is being carried out by those with a transient interest in tourism (Pearce, 1987). The need for the effective application of management techniques, the development of marketing plans and the effective implementation of marketing strategy is well recognized in the tourism industry (Go, Milne \& Whittles, 1992; Hawes, Taylor \& Hempe, 1991; Burke \& Lindblom, 1989). Traditional planning models and marketing planning processes have been adapted for the tourism industry. These conceptual models can form the basis for marketing planning for all the parties involved in the tourism industry (Heath \& Wall, 1992; Papadopoulos, 1989a; 1989b; Perdue \& Pitegoff, 1990).

It has been recognized that perceived risk plays an important role in consumer-buyer behaviour (for example, Bauer, 1967; Cox, 1967; Taylor, 1974; Engel, Blackwell \& Miniard, 1986). The study of perceived risk has been primarily focussed on consumer-buying behaviour with respect to goods (for instance Cunningham, 1967; Perry \& Hamm, 1965; Jacoby \& Kaplan, 1972; Kaplan, Szybillo \& Jacoby, 1974; Lutz \& Reilly, 1973; and Bettman, 1973). The literature relating to perceived risk for services is limited (for instance Lewis, 1976; Guseman, 1977; 1981; George, Weinberger \& Kelly, 1975; Bendixen \& Gault, 1995).

Roselius (1971) found empirical evidence that consumers have preferences for different methods of risk reduction for different types of loss or risk. He identified time, hazard, ego and money as the primary type of losses that consumers can incur. Tourism can thus be influenced if the potential tourist perceives a risk in travelling to that destination. 
There is considerable evidence to show a correlation between a decreasing rate of influx of tourists to a destination and an increased actual level of violence in the area (Enders, Sandler \& Parise, 1992; Hasek, 1991; Goodrich, 1991). The first proposition is as follows:

PI The South African Tourism industry illustrates the effects of isolation, violence and political uncertainty.

Segmentation of markets is a key factor in travel and tourism marketing with a number of empirical studies concentrating on this issue (Yong, Keng \& Leng, 1989; Javalgi, Thomas \& Rao, 1992). Plog (1981) classified travellers along two dimensions: allocentrism/psychocentrism and energy. Based on Plog's (1981) research, Nickerson \& Ellis (1991) suggested that the allocentrism and energy dimensions may be intercorrelated and proposed a revised typology. Other methods of segmenting markets have been suggested. These include nonusers of travel information to heavy users of information (Woodside \& Soni, 1991), trip demographics, media patterns, psychographics and the distance travelled (Etzel \& Woodside, 1982; Woodside \& Pitts, 1976; Bryant \& Morrison, 1980; Schewe \& Calantone, 1978; Weaver \& McCleary, 1984; McQueen \& Miller, 1985).

The second proposition is therefore as follows:

P2 The tourism market is highly segmented, resulting in the need to develop a differentiated marketing strategy for the different target markets.

Consumers engage in a series of problem-solving tasks when faced with a range of alternatives. The success of the travel agent depends on their superior access to information and specialist knowledge of markets and conditions. It enables this specialist to convey information, subjective opinion and motivating statements regarding a destination to the potential tourist, which may alter the tourist's perception of a destination and hence judgement of the tourism product (Maheswaran \& Sternthal, 1990). Exchanges which take place between the tourist and the provider of goods and services in the tourist destination itself are pertinent (Geva \& Goldman, 1989).

In the context of tourism, awareness or interest is created through the development of a desire for travel in order to accomplish one of the major travel motivators: desire for holiday/recreation, business needs, need to visit with friends or relatives (Yuan \& McDonald, 1990; Witt, Brooke \& Buckley, 1991).

One of the best-known and most frequently employed typecasting approaches classifies people as either introverts or extroverts. A very similar classification, with more application to the understanding of behavioural influences on tourist perceptions, categorizes people as either psychocentrics or allocentrics. Travel behaviour of these two categories of people differ significantly (Plog, 1981). Psychocentrics prefer the familiar in travel destinations and like common-place activities at travel destinations. Allocentrics prefer low level or nontourist areas. They enjoy the sense of discovering new experiences before others have visited the destination. We thus formulate proposition three:

P3 The tourist is influenced by a multitude of factors when making the decision to travel. These include money, time, energy, personal safety, psychological stress, media exposure and recommendations from a travel specialist.

Some consumers act in response to environmental pres. sures. An example is the global trend towards ecologically oriented tourism or 'ecotourism' which may have made the South African excursion more viable. Trends indicate that an increasing amount of tourists are seeking more nature interactive experiences (Krippendorf, 1982; Schwaninger, 1984). We thus propose the following:

P4 South Africa can capitalize on the international trend towards ecologically oriented tourism.

\section{Methodology}

International tourists were interviewed by one of the authors and asked to complete questionnaires in the intercontinental departure lounges at London's Heathrow airport. Heathrow was chosen as it is one of the world's busiest airports. A sample of 250 international tourists were interviewed.

\section{Sample}

The international tourists were stratified into those who had previously visited South Africa and those who had not. Interviews were conducted during the week 31 July to 8 August 1994. Fifty tourists from each of the areas representing the major South African tourist source markets were interviewed and asked to complete the questionnaires. These source markets are the United Kingdom, the United States of America and Canada, Europe, the Far East and Australia.

\section{Instrument}

The initial phase of the research comprised in-depth interviews with a number of experts in the tourism industry. Representation from the hotel, airline, tourism marketing and consulting, banking and foreign exchange industries was obtained. In addition, consultation with the South African Tourism Board (Satour), The Association of South African Travel Agents (ASATA), senior representatives from the Ministry of Tourism and the parliamentary standing committee on tourism was accomplished. The purpose of these interviews was firstly, to consolidate the theoretical frameworks presented in the literature review and secondly, to identify the critical success factors pertaining to the tourism industry and their intrinsic relationship with tourist perceptions in South Africa. Thirdly, to gain an appreciation of the general and competitive environment within which participants in the tourism industry operate. Finally, the interviews enabled the elaboration of key constructs for integration into the research instrument.

The questionnaire contained two sections. The first obtained demographic details such as area of origin, prior visits to South Africa, frequency of overseas travel and main sources of information on South Africa. The second section contained 22 statements. Respondents were asked to rate their extent of agreement with the statements presented according to a five-point Likert scale. This section examined the central theme of the research, namely the international perception of South Africa as a tourism destination in the post-apartheid era. 
The questionnaires were pre-tested amongst ten respondents with particular emphasis on assessment of comprehension, potential ambiguity and terminology. Required adjustments in phraseology were subsequently implemented.

\section{Data analysis}

The responses were captured and summarized in a spreadsheet utilizing Microsoft Excel. The resulting data was then analysed in Statistica and Number Cruncher Statistical System (NCSS) using descriptive statistics, correspondence analysis, factor analysis, cluster analysis, Chi-square tests, reliability analysis, ANOVA, non-parametric testing and t-tests.

\section{Results}

\section{Respondents}

All 250 questionnaires administered to international tourists at London's Heathrow airport were eligible for inclusion in the study.

Altogether 30 respondents (12\%) indicated that they had previously visited South Africa.

Altogether $41 \%$ of the respondents travelled overseas once or twice annually, $29 \%$ three or more times and $30 \%$ once or less annually.

Of all the respondents, $89 \%$ indicated that their main source of information on South Africa was through the media: television, radio or newspaper. Furthermore, 37\% indicated that they had gained information on this destination through friends or relatives who lived in, or had visited the country. Only $4.4 \%$ indicated that they had gained information on
South Africa through tourist information brochures. tourism boards or travel agents.

\section{Statement evaluation}

Correspondence analysis was used to rescale the data through an assessment of the Euclidean distance between scale points on the first two standard axes. These distances were then used to recreate the interval scale ranging from one through to five. This technique enabled statistical manipulation and valid statistical interpretation of inherently ordinal data by converting it into interval data (Bendixen \& Sandler, 1995). Results of the conversion of the Likert scale into its rescaled analogue are presented in Table 1.

It may be observed that the interval scale so derived is quite different from the usual allocation of numerical values one through five attributed to the standard Likert scale. The

Table 1 Rescaling of five-point Likert scale to interval scale

\begin{tabular}{lcccc}
\hline & $\begin{array}{c}\text { Ist axis } \\
\text { standard } \\
\text { co-ordinate }\end{array}$ & $\begin{array}{c}\text { 2nd axis } \\
\text { stundard } \\
\text { co-ordinate }\end{array}$ & $\begin{array}{c}\text { Euclidean } \\
\text { distance to } \\
\text { next point }\end{array}$ & $\begin{array}{c}\text { Five-point } \\
\text { interval } \\
\text { scale }\end{array}$ \\
\hline Strongly disagree & 1.967 & -0.635 & 1.686 & 1.00 \\
Disagree & 0.578 & -0.319 & 1.338 & 2.11 \\
Neutral & -0.407 & 1.226 & 2.082 & 2.99 \\
Agree & -0.916 & -0.793 & 0.987 & 4.35 \\
Strongly agree & -0.893 & -1.780 & - & 5.00 \\
\hline
\end{tabular}

Table 2 Mean rating of statement responses

\begin{tabular}{|c|c|}
\hline Statement & $\begin{array}{l}\text { Mean } \\
\text { rating }\end{array}$ \\
\hline South Africa's wildlife would be the main reason for me to visit that country & 3.98 \\
\hline The scenic attractions in South Africa would be a major reason for visiting that country & 3.91 \\
\hline South Africa offers many luxury resorts and world-class hotels to its tourists & 3.78 \\
\hline The ability to visit other Southern African countries would encourage the visit to South Africa & 3.57 \\
\hline Travelling to South Africa would be an emotionally or spiritually meaningful experience & 3.53 \\
\hline I was encouraged to visit South Africa after seeing the recent general elections and presidential inauguration & 3.49 \\
\hline I am attracted to South Africa because it is a relatively new travel destination and few people have been there before & 3.38 \\
\hline I would not visit South Africa without speaking to a travel agent or tour operator & 3.35 \\
\hline I am discouraged from visiting South Africa due to the high lovel of violence & 3.34 \\
\hline South Africa is an expensive travel destination & 3.30 \\
\hline The international media focus on South Africa makes me want to visit that country & 3.27 \\
\hline I am worried about coming to South Africa due to fears about my personal safety & 3.25 \\
\hline I feel that I would be taking a risk by visiting South Africa & 3.19 \\
\hline The weak South African currency makes it attractive to visit South Africa & 3.02 \\
\hline Staying at a bed and breakfast establishment in a black township interests me & 2.99 \\
\hline The distance involved in travelling to South Africa makes the visit unappealing & 2.91 \\
\hline My cultural ties would encourage me to visit South Africa & 2.73 \\
\hline Sanctions prevent people from visiting South Africa & 2.64 \\
\hline South Africa resembles other African states in its infrastructure and level of development & 2.23 \\
\hline I would not visit South Africa because I disapprove of its history of apartheid & 2.08 \\
\hline I am worried about what people at home will think of me visiting South Africa & 1.75 \\
\hline I would be attracted to South Africa if it offered more casinos and gambling facilities & 1.70 \\
\hline
\end{tabular}


rescaled mean ratings of these statements are presented in Table 2.

The data was subjected to principal component factor analysis. A six factor solution was accepted by virtue of all factors having eigen-values in excess of one and being readily interpretable. In addition, the scree plot of the eigen-values of this analysis demonstrated an elbow between the five and six factor solution. These six factors explained an acceptable $54.43 \%$ of the co-variance in the rescaled data. The varimax rotated factor loadings are presented in Table 3.

\section{Naming of the factors}

The factors derived were named accordingly to the perceptual attributes which loaded onto them, and the average statement score for that factor. The factor names represent the essence of the current perceptions of international tourists on South Africa.

\section{Factor I: South Africa is a potentially hazardous tourist des- tination}

The statements 'discouraged by violence', 'worried about personal safety' and 'taking a risk' load onto this factor. Factors which have the capacity to physically or emotionally endanger the tourist are shown to rank as fundamental considerations. Clearly, where the integrity of the tourist is imperilled, there are considerable perceptual forces constraining travel to that area. The average score of 3.26 demonstrates a moderate affirmation of the perception for potential risk associated with this tourist destination.
Factor 2: There is value in the current South African tourism experience

The statements which load onto this factor provide more insight into the dilemma facing potential tourists to South Africa. The statement 'emotionally or spiritually meaningful' is contrasted against 'expensive' and 'distance unappealing'. The average score of 3.25 reflects an agreement with the former and relative disagreement with the latter two statements. The overall perception therefore is that South Africa represents value by virtue of its current elevated political status. This perceived value negates to some extent the expense associated with the excursion and the inconvenience involved in travelling there.

\section{Factor 3: South Africa is a prime ecotourism destination}

'Wildlife main reason to visit' and 'scenic attractions' are the statements constituting this factor. They confirm the status of South Africa as a superior ecotourism product, and its continued tourist attracting potential. The average statement score of 3.89 confirms this definition and emphasizes the central importance of the natural resource in the South African tourism portfolio.

Factor 4: Apartheid is dead, but what is the new South Africa'?

The statements 'history of apartheid discourages visit' and 'worried about what people at home may think' load onto this factor. They represent the substance of the apartheid stigma and the impact of a global chorus of condemnation. The low

Table 3 Rotated factor loadings

\begin{tabular}{|c|c|c|c|c|c|c|c|}
\hline Statement & Factor 1 & Factor 2 & Factor 3 & Factor 4 & Factor 5 & Factor 6 & Communality \\
\hline Scenery & -0.0258 & -0.1150 & +0.7881 & +0.0046 & +0.0002 & +0.1004 & 0.6451 \\
\hline Violence & +0.8809 & -0.0123 & +0.0659 & +0.0505 & +0.1549 & +0.1291 & 0.8238 \\
\hline Expensive & -0.0333 & +0.6881 & +0.1000 & +0.2699 & -0.2353 & -0.2403 & 0.6705 \\
\hline Elections/inauguration & +0.2842 & -0.0146 & -0.1947 & -0.0269 & +0.6443 & -0.0130 & 0.5349 \\
\hline Distance unappealing & +0.0502 & +0.5657 & -0.0332 & +0.4077 & +0.0669 & -0.1967 & 0.5335 \\
\hline More casinos & -0.0194 & +0.0404 & -0.1035 & +0.3046 & +0.2184 & +0.3103 & 0.2495 \\
\hline History of apartheid & +0.2293 & -0.0827 & +0.0103 & +0.7164 & -0.0494 & -0.0325 & 0.5762 \\
\hline Personal safety & +0.8673 & +0.0317 & -0.0116 & +0.1369 & -0.0154 & -0.0057 & 0.7723 \\
\hline Regional travel & +0.0546 & +0.1892 & -0.1552 & +0.1185 & -0.0664 & +0.7185 & 0.5976 \\
\hline Media focus & -0.3023 & -0.0267 & +0.1305 & +0.2041 & +0.7331 & -0.0750 & 0.6939 \\
\hline Meaningful & -0.0387 & +0.7890 & -0.1181 & -0.1285 & +0.0663 & +0.1022 & 0.6693 \\
\hline Africa standards & +0.0513 & -0.0003 & -0.2831 & +0.2570 & -0.2280 & +0.1736 & 0.2309 \\
\hline Wildlife & +0.0327 & -0.0040 & +0.8291 & +0.0025 & -0.0411 & -0.0694 & 0.6950 \\
\hline Home image & -0.0249 & +0.0395 & -0.0401 & +0.7078 & +0.2276 & -0.0812 & 0.5632 \\
\hline New destination & +0.1695 & +0.2619 & +0.1707 & +0.3914 & +0.1753 & +0.0899 & 0.3185 \\
\hline Risk & +0.7232 & -0.1706 & -0.0581 & +0.2259 & -0.1040 & -0.2249 & 0.6680 \\
\hline Weak currency & +0.0575 & +0.0831 & +0.3413 & -0.4048 & +0.1561 & +0.3372 & 0.6034 \\
\hline Cultural ties & -0.1012 & +0.4653 & +0.0857 & -0.0661 & +0.3009 & +0.1297 & 0.3458 \\
\hline Sanctions & +0.1287 & +0.1554 & +0.2201 & +0.1123 & +0.2803 & +0.1543 & 0.2041 \\
\hline Luxury resorts & -0.1999 & -0.2016 & +0.3432 & -0.0235 & -0.0561 & +0.5309 & 0.4839 \\
\hline Travel agent & +0.3274 & -0.0767 & +0.0153 & +0.5366 & -0.1465 & +0.2712 & 0.4963 \\
\hline Township B \& B & -0.0478 & +0.3475 & -0.2137 & -0.1723 & -0.0894 & +0.3059 & 0.5985 \\
\hline
\end{tabular}


average score of 2.39 however, represents considerable disagreement with these statements. The interpretation of the perception of these tourists, therefore, is that this stigma is no longer an issue. The post-apartheid era is a perceived reality.

The picture is not complete, however, as the statement 'I would not visit without speaking to a travel agent' also loads onto this factor. The concentrated media exposure of South Africa may have made the potential tourist well aware of the demise of apartheid and the progression into a transitional phase. The tourist, however, is less sure about the state of the South African tourism industry. It is apparent therefore that while the political changes are well known, the tourism product is less so.

\section{Factor 5: Recent changes are encouraging}

'Encouraged by elections and inauguration' and 'media focus encourages visit' are the statements which load onto this factor. This combination reconfirms the impact of the media on the travel decision. The positive light in which the recent changes in South Africa have been portrayed have encouraged the tourist, and may have served to decrease the perception of risk and uncertainty traditionally associated with that destination. The average score of 3.39 also represents a confirmation of this position.
Factor 6: South Africa offers a comprehensive tourism product

This factor is characterized by the positive statements which load onto it. 'Ability to visit other Southern African states' and 'luxury resorts', define a destination which provides attractive opportunities for the potential tourist. The high average score of 3.68 suggests firm agreement with these contributors to positive tourist utility. The scope to explore a range of tourism options within the same destination makes the product a well diversified and comprehensive offering. Table 4 summarizes the pertinent elements of the factors analysis.

The factors were tested for reliability using the Cronbach alpha coefficient as a measurement. The scores demonstrated some variation but were considered acceptable, ranging from 0.50 to 0.81 .

\section{Segmentation}

Factor scores were calculated as the mean of the statements loading onto that factor. These scores were then subjected to k-means cluster analysis. A six cluster solution yielded a $54.78 \%$ reduction in variance and displayed an elbow in the scree plot of variance reduction.

Table 4 Factor analysis: international tourists

\begin{tabular}{|c|c|c|c|c|}
\hline & Factor name & Statement & $\begin{array}{l}\text { Rotated } \\
\text { factor } \\
\text { loading }\end{array}$ & $\begin{array}{c}\text { Cronbach } \\
\text { alpha } \\
\text { (factor ave) }\end{array}$ \\
\hline \multirow[t]{3}{*}{$\mathbf{I}$} & South Africa is a & 2. Discouraged by violence & 0.88 & 0.81 \\
\hline & potentially hazardous & 8. Fears about personal safety & 0.87 & $(3.26)$ \\
\hline & tourist destination & 16. Perceived risk in coming to $\mathrm{SA}$ & 0.72 & - \\
\hline 2 & There is value in the & $\begin{array}{l}\text { II. SA visit emotionally/spiritually } \\
\text { meaningful }\end{array}$ & 0.79 & 0.65 \\
\hline \multirow{2}{*}{2} & current South African & 3. Expensive travel destination & 0.69 & (3.25) \\
\hline & tourism experience & 5. Distance to SA makes visit unattractive & 0.57 & - \\
\hline \multirow[t]{2}{*}{3} & South Africa is a prime & 13. Wildlife main reason for visit & 0.83 & 0.75 \\
\hline & ecotourism destination & 1. Scenery major attraction & 0.79 & $(3.89)$ \\
\hline \multirow[t]{3}{*}{4} & Apartheid is dead (but & 7. History of apartheid prevents visit & 0.72 & 0.60 \\
\hline & what is the new 'South & 14. Concerns about home image & 0.71 & $(2.39)$ \\
\hline & Africa'?) & 21. Travel agent & 0.54 & - \\
\hline \multirow[t]{2}{*}{5} & Recent changes in South & 10. Intnl media focus encourages visit & 0.73 & 0.50 \\
\hline & Africa are encouruging & 4. Elections/inauguration encourage visit & 0.64 & $(3.42)$ \\
\hline \multirow[t]{2}{*}{6} & South Africa offers a com- & 9. Regional travel opportunities attractive & 0.72 & 0.50 \\
\hline & prehensive tourism product & 20. SA has many luxury resorts and hotels & 0.54 & (3.68) \\
\hline
\end{tabular}

Table 5 Factor score means by cluster

\begin{tabular}{lccccccc}
\hline & Cluster 1 & Cluster 2 & Cluster 3 & Cluster 4 & Cluster 5 & Cluster 6 & Average \\
\hline Factor 1 & 3.01 & 3.73 & 1.73 & 3.69 & 4.23 & 3.78 & 3.16 \\
Factor 2 & 3.49 & 2.61 & 3.40 & 3.77 & 3.67 & 3.39 & 3.40 \\
Factor 3 & 4.39 & 3.55 & 3.51 & 4.51 & 4.27 & 1.00 & 3.89 \\
Factor 4 & 1.74 & 3.22 & 1.42 & 2.51 & 1.60 & 2.80 & 2.10 \\
Factor 5 & 4.36 & 3.81 & 3.06 & 2.86 & 3.22 & 3.04 & 3.42 \\
Factor 6 & 4.12 & 3.15 & 3.74 & 4.19 & 3.74 & 3.07 & 3.67 \\
$\mathrm{n}=$ & 61 & 49 & 49 & 42 & 43 & 6 & - \\
\hline
\end{tabular}


The mean factor scores for the resulting six clusters are presented in Table 5. These clusters were interpreted in terms of the definitions of the factors described in the factor analysis. The process was utilized to segment the sample into perceptual subgroups, enabling a richer understanding of the tourist market in the context of these definitions.

\section{Cluster 1: inspired enthusiasts}

The first cluster representing $24.40 \%$ of respondents, is characterized by above average scores for factors 3,5 and 6 and disagreement with the statements constituting factor 4 . The combination demonstrates that this cluster of respondents view South Africa as a superior tourism product, and are encouraged by the changes which have followed the fall of apartheid. This cluster represents a premium tourist destination.

\section{Cluster 2: disinterested anachronists}

The second cluster, representing $19.60 \%$ of respondents is characterized by above average agreement with the statements of factors 1 and 4 , and disagreement with those of factor 6 . These attributes contrast heavily with those of cluster 1. They represent a segment of tourists who believe that the destination is dangerous, and still characterized by active apartheid. In addition, they perceive little of the comprehensive tourism product in that destination. They are indeed a group which know very little of the changes which have transpired, and have a truly antiquated vision of the country.

\section{Cluster 3: intrepid ignorants}

The third cluster is characterized by disagreement with the statements of factors 1 and 4 . They constitute $19.60 \%$ of respondents. This is a segment of tourists who perceive the favourable political transformation which has taken place, and for whom there is little risk associated with the destination. Importantly however, they show no recognition of its formal tourism attributes

They represent a fairly sizeable group of potential tourists which has little geographical, yet some, probably mediabased, political knowledge of South Africa, in addition to a low risk profile. This combination characterizes a generation of potential travellers, conceivably the youth of the tourism market, for whom the South African destination was never a tourism option, due to the era of isolation which the country underwent.

\section{Cluster 4: nervous enthusiasts}

This cluster representing $16.80 \%$ of respondents is characterized by above average agreement with the statements of factors 1,3 and 6 . This is a risk averse segment which is well aware of the attractions of the South African tourism product, but which is turned away by the perception of violence and potential for personal harm. Until these fears are dissipated they remain only latent possibilities for the South African tourism industry.

\section{Cluster 5: unconvinced hesitants}

The fifth cluster, representing $17.20 \%$ of respondents is characterized by above average agreement with the statements of factors 1 and 3 and disagreement with those of factor
4. These are tourists who have strongly positive perceptions of the ecotourism potential of South Africa. Although they are aware of the political changes which have taken place, the associated violence has failed to convince them that these changes will have the desired effect. As such they remain sceptical, and for the time being, they will also stay away.

\section{Cluster 6: unenlightened negatives}

This small cluster representing $2.40 \%$ of respondents, is characterized by above average agreement with factor 1 and disagreement with factors 3 and 6 . They represent a segment of tourists who perceive nothing of the attractions of the South African tourism product and who only distinguish the destination by its potential dangers. This stubbornly negative outlook carries little prospect for short-term revision. The relative size of these clusters or market segments is illustrated in Figure 1.

\section{Tests of association}

These clusters, representing tourist market segments, were then analysed for association relating to the demographic variables: area of origin, frequency of overseas travel and previous visit(s) to South Africa. To achieve this, the data was subjected to Chi-square tests, at a $5 \%$ significance level.

Cluster 6, 'unenlightened negatives', was excluded from this analysis as the representation of this cluster on the contingency table was too low, and transgressed the 'rule of five'. This states that expected frequency counts of less than five in one cell of a contingency table, may give rise to incorrect inferences from $\mathrm{X}^{2}$ hypothesis tests, and are hence too small to use (Levin \& Rubin, 1991). Summary results of these chisquare tests are shown in Table 6.

This analysis demonstrates that clusters are independent of 'area of origin' and 'previous visit(s) to South Africa'. Significant dependency, however, was demonstrated with respect to 'frequency of overseas travel'. Table 7 demonstrates the cluster characteristics with respect to this demographic variable.

This analysis enabled further insight into the characteristics of the clusters according to frequency of overseas travel. The proportions suggest that high frequency travellers constitute much of the positive tone of international tourists regarding travel to South Africa. Their high representation in the

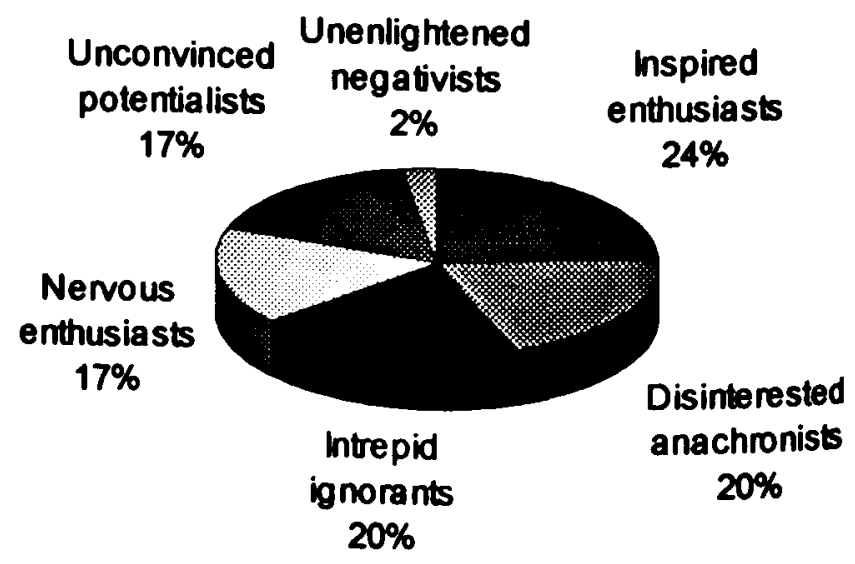

Figure 1 South African tourist market segments 
Table 6 Chi-square tests of independence

\begin{tabular}{lccc}
\hline & $\begin{array}{c}\text { Area of } \\
\text { origin }\end{array}$ & $\begin{array}{c}\text { Frequency of } \\
\text { oversens travel }\end{array}$ & $\begin{array}{c}\text { Previous visit(s) } \\
\text { to South Africa }\end{array}$ \\
\hline Degrees of freedom & 16 & 8 & 4 \\
Chi-square statistic & 5.827 & 22.678 & 2.612 \\
Chi-square (crit) & 26.296 & 15.507 & 9.488 \\
Probability level & 0.989 & $\mathbf{0 . 0 0 4}$ & 0.625 \\
\hline
\end{tabular}

Table 7 Cluster proportions: frequency of overseas travel

\begin{tabular}{lccccc}
\hline & $\begin{array}{c}\text { Cluster I } \\
\text { Inspired }\end{array}$ & $\begin{array}{c}\text { Cluster 2 } \\
\text { Disinterested }\end{array}$ & $\begin{array}{c}\text { Cluster 3 } \\
\text { Intrepid } \\
\text { Frequency } \\
\text { enthusiasts anachronists } \\
\text { ignorants } \\
\text { \% }\end{array}$ & $\begin{array}{c}\text { Cluster 4 } \\
\text { Nervous } \\
\text { enthusiasts } \\
\%\end{array}$ & $\begin{array}{c}\text { Cluster 5 } \\
\text { Unconvinced } \\
\text { hesitants } \\
\%\end{array}$ \\
\hline High & 44.3 & 26.5 & 24.4 & 30.9 & 18.6 \\
Moderate & 32.8 & 30.6 & 48.9 & 54.8 & 37.2 \\
Low & 22.9 & $\mathbf{4 2 . 9}$ & 26.5 & 14.3 & 44.2 \\
\hline
\end{tabular}

favourable cluster 1 , and their comparatively low representation in a cluster with a negative outlook (cluster 5), supports this inference.

Low frequency travellers conversely, were shown to have a relatively pessimistic perception of tourism to South Africa. Their high proportion in 'negative' clusters 2 and 5 and their low representation in an enthusiast segment (cluster 4), conveys a message of scepticism and misgiving from this group of international tourists.

Moderate frequency travellers interestingly, show a dominance in two contrasting segments. They represent a high proportion of cluster 3, 'intrepid ignorants', and cluster 4, 'nervous enthusiasts'. This apparent inconsistency is reconciled by recognizing that neither of these segments have strongly negative connotations. While an element of caution is suggested in cluster 4 , it remains an enthusiast-type segment. In the same way, cluster 3 , whilst suggesting ignorance of the South African tourism product, conveys an attitude of potential for travel. Overall, this group of international travellers is characterized by a indecisive orientation towards tourism to South Africa, either through anxiety or ignorance. For completeness, the remaining proportions are shown in Table 8.

\section{Comparative assessment of statement responses}

The rescaled statement responses were finally subjected to analysis of variance (ANOVA), Kruskal-Wallis and t-tests to ascertain whether significant differences existed between sample strata with respect to key demographic variables. Tests were conducted at a 5\% significance level.

\section{Geographic variations}

ANOVA was applied to the rescaled data which was filtered by area of origin. ANOVA was deemed appropriate in this regard as the number of observations (respondents) in each geographical group was identical. Inference made about the sample means could thus be deemed to be minimally affected by possible unequal population variances (Miller \& Wichern, 1977). The results are summarized in Table 9.
Table 8 Cluster proportions: area of origin and previous visit to South Africa

\begin{tabular}{lccccc}
\hline & $\begin{array}{c}\text { Cluster 1 } \\
\text { Inspired } \\
\text { enthusiasts anachronists } \\
\text { \% }\end{array}$ & $\begin{array}{c}\text { Cluster 2 } \\
\text { Disinterested }\end{array}$ & $\begin{array}{c}\text { Cluster 3 } \\
\text { Intrepid }\end{array}$ & $\begin{array}{c}\text { Cluster 4 } \\
\text { ignorants } \\
\text { Nervous }\end{array}$ & $\begin{array}{c}\text { Cluster 5 } \\
\text { enthusiasts }\end{array}$ \\
$\begin{array}{lcccc}\text { Unconvinced } \\
\text { hesitants }\end{array}$ \\
\hline Origin & & & & $\%$ & $\%$ \\
UK & 21.3 & 22.4 & 14.3 & 21.4 & 20.9 \\
USA/Canada & 23.0 & 18.4 & 20.4 & 16.7 & 20.9 \\
Europe & 21.3 & 16.3 & 18.4 & 21.4 & 23.3 \\
Far East & 16.4 & 18.4 & 24.5 & 21.4 & 23.3 \\
Australia & 18.0 & 24.5 & 22.4 & 19.0 & 11.6 \\
Previous visit & & & & & \\
No & 83.6 & 91.8 & 91.8 & 85.7 & 86.1 \\
Yes & 16.4 & 8.2 & 8.2 & 14.3 & 13.9 \\
\hline
\end{tabular}

This analysis demonstrates interesting differences in mean perceptions between geographical tourist strata. Respondents from the United Kingdom showed a significantly higher agreement with the statement 'cultural ties encourage visit'. This perception is understandable in terms of South Africa's history as a British colony and member of the Commonwealth. It may also reflect the large numbers of British immigrants resident in South Africa and reciprocally, the equally large South African expatriate population resident in that country.

Respondents from the USA and Canada inferred that they would be more encouraged to visit South Africa if it had more casinos and gaming facilities. This group were also most concerned about what people at home would think of them visiting South Africa.

Respondents from the Far East demonstrated a significantly stronger perception that South Africa was similar to other African states compared with the other tourist strata. Correspondingly, they also demonstrated a significantly lower perception of the presence of luxury resorts and world-class hotels in this destination. This indicates a lower overall knowledge of the South African product and confirms the

Table 9 ANOVA: geographic variations in statement responses

\begin{tabular}{|c|c|c|c|c|c|c|}
\hline & Prob $>F$ & UK & USA & EUR & F/E & AUS \\
\hline Expensive & 0.000 & & & & & $\uparrow$ \\
\hline Distance unappealing & 0.000 & & & & & $\uparrow$ \\
\hline More casinos & 0.000 & & $\uparrow$ & & & \\
\hline Meaningful & 0.020 & & & & & $\uparrow$ \\
\hline Africa standards & 0.000 & & & & $\uparrow$ & \\
\hline Home image concerns & 0.040 & & $\uparrow$ & & & \\
\hline New destination & 0.047 & & & & & $\uparrow$ \\
\hline Cultural ties & 0.049 & $\uparrow$ & & & & \\
\hline Luxury resorts & 0.015 & & & & $\downarrow$ & \\
\hline Township B \& B & 0.011 & & & & & $\uparrow$ \\
\hline $\begin{array}{l}\text { EUR: Europe; F/E: } \\
\text { America \& Canada }\end{array}$ & East; & US: & ralia; & USA: & Jnited & tares of \\
\hline
\end{tabular}


status of the Far East as an emerging tourist source market. It also highlights the need for greater market development and image building in this area.

Australian respondents showed significantly higher agreement with the statements 'expensive tourism destination' and 'distance unappealing' than the rest of the sample. This is understandable in terms of the greater perceived remoteness of this area from South Africa than the others. These respondents also perceived the destination to have more emotional or spiritual meaningfulness than the other of those from the other geographical areas. Interestingly, the Australian sample also stated a significantly greater perceived attraction to South Africa by virtue of its relative 'newness' as a tourism destination. In addition they were significantly more interested in staying at a bed and breakfast establishment in one of the black townships in South Africa. These characteristics identify the Australian group as distinctly more inquisitive and explorative than the other tourist strata. As such they more closely align with the allocentric tourist typology described in the literature.

\section{Variations by frequency of overseas travel}

The Kruskal-Wallis test was applied to the rescaled data and filtered by frequency of overseas travel. This is shown in Table 10.

The output demonstrates that low frequency overseas travellers find the distance involved in travelling to South Africa significantly less appealing than their higher frequency counterparts. Whether the low frequency of such travel is the cause of this aversion, or whether the aversion to long distance travel is the primary reason for the low annual frequency of overseas travel is, however, akin to the chicken-or-the-egg dilemma! This group also demonstrates greater concern about their home image in terms of what people will think of them visiting South Africa.

Moderate frequency travellers found significantly greater appeal in the potential for visits to other Southern African countries. Their lower frequency of travel may explain their

Table 10 Kruskal-Wallis test: variations by frequency of overseas travel

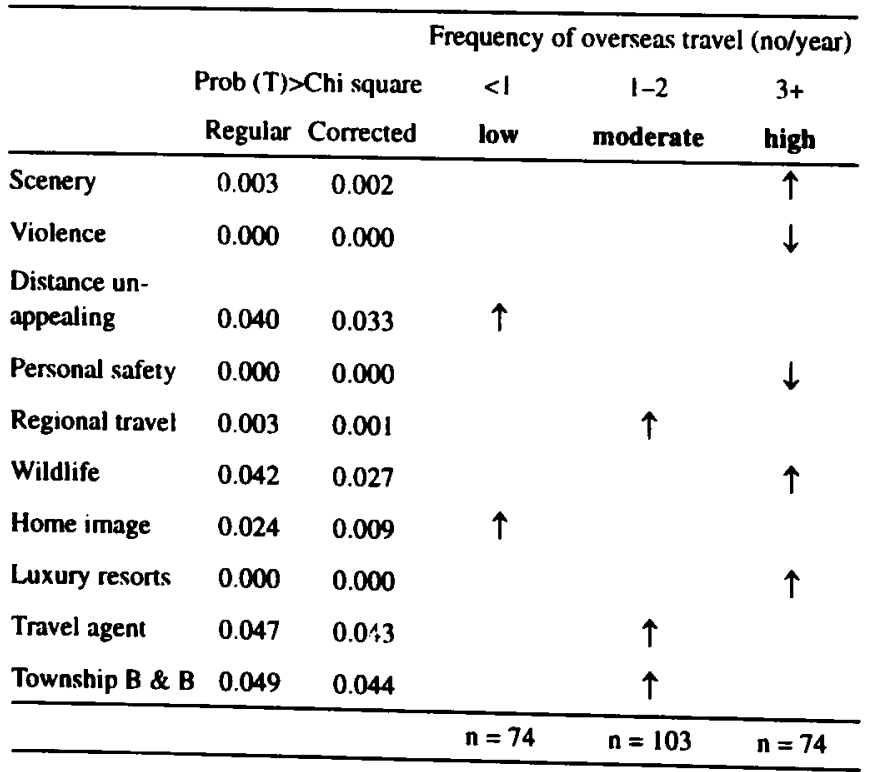

desire to squeeze more into the few excursions that they do undertake, than their higher frequency counterparts. Their higher perceived attraction for a bed and breakfast experience in a black township may also be explained by this desire, but may also reflect a level of ignorance regarding the current potential dangers of such accommodation. This group was also more likely to seek the advice of a travel agent before visiting South Africa than the other two strata. This could be explained by the lower requirement for the travel agent of the more experienced high frequency traveller, and in the case of the low frequency traveller, the relative aversion to long distance travel may forego the requirement to consult a specialist in the first place.

Higher frequency travellers showed a significantly greater appreciation of the scenic attractions, wildlife, luxury resorts and world-class hotels. This may be partially explained by the greater exposure of the high frequency traveller to international travel brochures, in-flight magazines or fellow travellers. Interestingly, they also demonstrated a significantly lower aversion to the violence and concern about their personal safety in South Africa.

\section{Variations by previous visit to South Africa}

T-tests were performed on the rescaled data to demonstrate any differences existing between respondents by virtue of a previous visit to South Africa. Table 11 summarizes these findings.

This analysis demonstrates that the perceptual differences which do exist between these two groups are mostly logical, and explained simply by experiential knowledge of the South African destination.

Tourists who have previously visited South Africa find the distance required to travel to this destination significantly less unappealing than people who have never done so. They are less likely to consult a travel agent regarding a future visit to this country and are significantly less attracted to the bed and breakfast opportunity in a black township. Interestingly, tourists who have previously visited South Africa have a significantly lower overall perception of risk associated with travel to this destination, suggesting once again the over elaboration of this aspect of South Africa by the media.

Tourists who have never visited South Africa demonstrate significantly less knowledge of the existence of luxury resorts and hotels in South Africa, as well as an ignorance of the

Table 11 t-tests: variations by previous visit to South Africa

\begin{tabular}{lccc}
\hline & \multicolumn{3}{c}{ Previous visit to South Africa } \\
& Prob & YES & NO \\
\hline Violence & 0.000 & $\downarrow$ & \\
Distance unappealing & 0.009 & $\downarrow$ & \\
Safety & 0.002 & $\downarrow$ & \\
Risk & 0.008 & $\downarrow$ & \\
Weak currency & 0.049 & & $\downarrow$ \\
Luxury resorts & 0.047 & & $\downarrow$ \\
Travel Agent & 0.000 & $\downarrow$ & \\
Township B\&B & 0.010 & $\downarrow$ & \\
\hline
\end{tabular}


favourable exchange rate differential between South Africa and its major tourist source markets.

\section{Recommendations and implications}

The results clearly support the first proposition, that the South African tourism industry illustrates the effects of isolation, violence and political uncertainty. It also supports the current evidence to show a correlation between a decreasing rate of influx of tourists to a destination and an increased actual level of violence in the area (Enders, Sandler \& Parise, 1992; Hasek, 1991; Goodrich, 1991). It thus reinforces the long recognized fact that perceived risk plays an important role in consumer buyer behaviour.

The findings also strongly support the second proposition that the tourism market is highly segmented, resulting in the need to develop a differentiated marketing strategy for the different target markets. A number of other studies also found that segmentation is a key factor in travel and tourism marketing (Yong, Keng \& Leng, 1989; Javalgi, Thomas \& Rao, 1992).

The third proposition is supported. The tourist is influenced by a multitude of factors when making the decision to travel. These include money, time, energy, personal safety, psychological stress. media exposure and recommendations from a travel specialist. These findings support previous studies (Yuan \& McDonald, 1990; Witt, Brooke \& Buckley, 1991).

The fourth proposition is supported as some consumers are responding to environmental awareness campaigns. South Africa can capitalize on the international trend towards ecologically oriented tourism. This supports the trend that indicates an increasing amount of tourists are seeking more nature interactive experiences.

The propositions accepted that the present status of the South African tourism industry illustrated the obvious effects of isolation, violence and political uncertainty. They postulated, however, that the current perceptual consciousness of international tourists regarding South Africa as a tourist destination transcended these overt issues and reflected a multidimensional problem.

These observations highlight the difficulties facing South African tourism formation bodies or tourism marketing agencies. Efforts at promoting tourism are strongly influenced by the tone of the international media, which convey much of the persuasive content of the information presented to potential tourists. A significant prerequisite therefore, for successful tourism promotion, is favourable media representation of the destination. In this context, all endeavours by these tourism bodies are secondary to their priority marketing implications.

The segmentation of international tourists identified six perceptual variants in the context of the South African travel decision. The diversity of the tourist market segments so identified carries significance in terms of the marketing options available for this tourism destination.

The inspired enthusiasts group are clearly the most promising segment in terms of their clear perception of value associated with the South African product. A push-type marketing strategy aimed at the tourism product channels of distribution, that is tour operators and travel agents, could convert this exiting enthusiasm into a positive travel decision. This could be achieved through attractive tour packages or other incentives offered by these parties.

The disinterested anachronists, conversely, are a much more complex segment, with considerable obstructive influences regarding the South African travel decision. Definitive primary action in terms of national image building is required, but even these may not convert the fairly resistent perceptions of this group.

Intrepid ignorants represent a further perceptual variant on the awareness spectrum. This segment has considerable potential, and a definitive role for tourism formation bodies with regard to this group is present. Market development through promotion of the product by these bodies, to both the trade and the tourist, could build an improved market in this segment.

The segment 'hesitant enthusiasts' requires unequivocal reassurance as to the reduction in potential for personal harm while touring South Africa. The most fundamental priority in this regard lies in the creation of a national atmosphere of reconciliation, combined with the establishment of a tourist protection infrastructure. The state must develop a touristoriented culture through education programmes amongst the general population.

Unconvinced hesitants are another difficult market segment to convert. They have a positive perception of the destination and its politics but are likely to adopt a wait-and-see approach to their decision making. The role of the state and an emphasis on internal stability and peace obviously have a role to play in this regard, but this market segment may well just require some time before reconsidering this destination.

Unenlightened negativists see the South African tourism product as an essentially unfavourable package. They see no value in the ecotourism potential or the comprehensive nature of the product, which they also perceive as dangerous. This small segment should not be a target market.

\section{Market focus regions}

The identification and characterization of these perceptual tourist market segments enable the construction of a prioritization grid in terms of the marketing implications of each segment. Figure 2 provides a graphical representation of these market segments plotted in terms of two dimensions. Firstly, the extent of the primary attraction to the South African tourism product and secondly, the relative marketing cost of converting a potential tourist into a visitor to South Africa.

Primary attraction depicts the degree of perceived initial attraction the potential tourist market segment has towards the destination. It provides a perceptual point of reference from which this segment must move for conversion to a derived or secondary state of attraction.

Cost of conversion illustrates the relative cost incurred in the conversion process and embraces the costs of all efforts expended at gaining tourist market share in a competitive tourism environment.

Region I correlates with the segment of 'inspired enthusiasts'. They are characterized by the highest primary attraction status and the lowest cost of conversion. It represents an identified prime marketing focus area and it also represents a potentially high yield and major opportunity for rapid marketing fruition. 


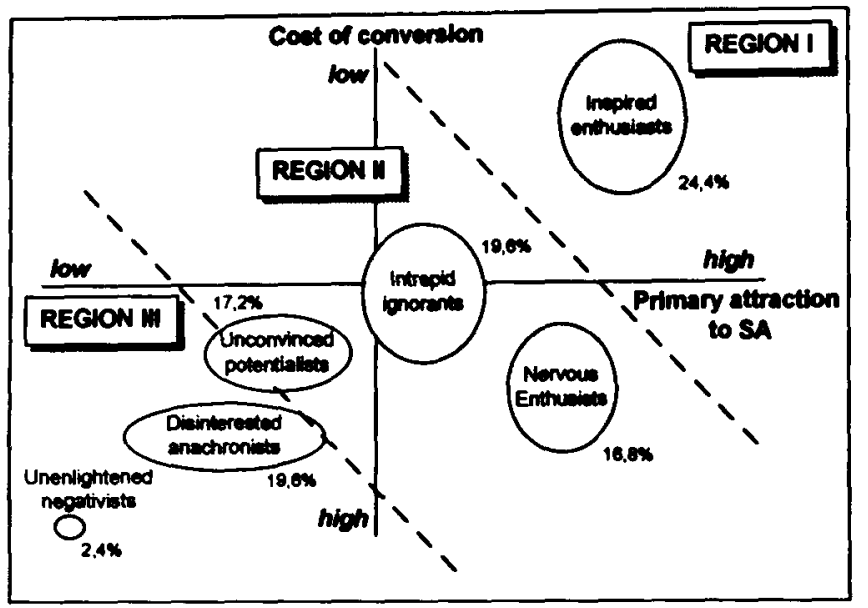

Figure 2 Marketing focus regions

Region Il embraces three market segments with intermediate levels of primary attraction and moderate to high conversion costs. Whilst this region identifies a diverse perceptual group of tourists in terms of the marketing requirements demanded by each segment, it represents up to $53.6 \%$ of the tourist population investigated. It thus demonstrates a large and essential population of potential tourists in the medium term. This group of tourist segments is a highly dependent group. All three identified segments have their own idiosyncracies and perceptual drivers. These include perceived safety (nervous enthusiasts), perceived ongoing political progress (unconvinced hesitants) and perceived product value (intrepid ignorants). It is these fastidious characteristics which are the basis for high marketing effort requirements.

Region III represents a group of two tourist market segments which rate highly in terms of required effort and low on primary attraction criteria. They are characterized by strongly negative perceptual appraisals of the South African tourism product. This region isolates a portion of international tourists which may well represent a poor trade-off between potential returns and cost of expended marketing effort.

The successful conversion of the region II group of tourist market segments will be the fundamental basis for the longterm growth and prosperity of the South African tourism industry. The ability to transform these perceptual constraints into positive tourism drivers is the challenge which confronts all the members of the tourism industry. The process of testing for association of perceptual tourist market segments with respect to their demographic strata identified two further attributes which have important implications for the marketing of the South African tourist destination.

Firstly, the process demonstrated a lack of dependency of these segments on their geographical area of origin, as identified by the application of chi-square tests. The marketing implications of this finding are that relatively uniform tourism promotional efforts could potentially be targeted at each perceptual market segment, rather than undertaking geographically based, diverse marketing programmes implemented on a regional basis.

Secondly, the process demonstrated a distinct contrast in the perceptions of international tourists based on their travel patterns, and in particular, the frequency of overseas travel. A definite association between a high frequency of such travel, and a firmly positive perception of the South African destination was identified. It provides an essential clue as to the basis for perception modification of international tourists. Exposure of high frequency travellers to information sources is the key.

\section{Conclusion}

This study has identified many of the critical factors which need to be addressed to contribute towards an effective strategic alignment of the tourism industry in post-apartheid South Africa. It is a good example of a perilous or high-risk product. It illustrates that consumers will find methods of risk reduction to the point that some segments will not even consider travelling to the country. Risk reducing steps will have to form a key part of the future tourist marketing strategy. Risk reducing steps such as encouraging police to reduce the levels of violence in the country as a whole and increasing foot patrols in tourist areas is essential. As a form of promotion, travel agents need to make increasing use of personal recommendations and references to previous tourists to South Africa. The government and tourism authorities need to promote political stability in the country, as this will increase the positive images conveyed by the media to potential tourists overseas.

Further research is needed to guage the relative success of South African tourism promotional efforts in the future. The impact of changes in infrastructure and environmental systems on tourism should also be monitored.

\section{Acknowledgement}

The authors thank Marius Leibold for his constructive suggestions and advice on an earlier draft of this article.

\section{References}

Bauer, R.A. 1960. 'Consumer behaviour as risk taking'. In Hancock, R.S. (ed.). Dynamic marketing for a changing world. Chicago: American Marketing Association, pp. 23-33.

Bendixen, M. \& Gault, G. 1996. 'Consumer evaluation of perceived risks for goods and services', South African Journal of Business Management, article accepted for publication.

Bendixen, M. \& Sandler, M. 1995. 'Converting verbal scales to interval scales using correspondence analysis', Management $D y$ namics: Contemporary Research, pp.32-50.

Bettman, J.R. 1973. 'Perceived risk and its components: a model and empirical test', Journal of Marketing Research, 10: 184-190.

Botha, F. 1993. 'Opportunities for the tourist industry', Travel Conference, Johannesburg.

Bryant, B. \& Morrison, A. 1980. 'Travel market segmentation and the implementatioon of market strategies', Journal of Travel Research, 18: 28.

Burke, J.F. \& Lindblom, L.A. 1989. 'Strategies for evaluating direct response tourism marketing', Journal of Travel Research, 28: 3337.

Caras, D., Saunders, G., Bird, J. \& Kleynhans, C. 1993. Tourism talk: a bulletinon tourism and its allied industries in Southern Africa. Johannesburg.

Cox, D.F. 1967. 'Risk handling in consumer behaviour in risk taking and information handling in consumer behaviour risk taking and information handling in consumer behaviour'. In D.F. Cox (ed.). Boston: Graduate School of Business Administration, Harvard University, pp.34-81.

Cunningham, S.M. 1967. 'The major dimensions of perceived risk in 
risk taking and information handling in consumer behaviour. In D.F. Cox (ed.). Boston: Graduate School of Business Administration. Harvard University, pp.82-108.

De Vaal. A. 1994. 'Tourism in South Africa: the way forward', National Tourism Forum Conference, Midrand, February.

Enders, W.. Sandler, T.\& Parise, G.F. 1992. 'An econometric analysis of theimpact of terrorism on tourism', Kyklo. 45: 531-554.

Engel, J.F.. Blackwell. R.D. \& Miniard, P.W. 1986. Consumer behaviour. Chicago: The Dryden Press.

Etzel, M.J. \& Woodside, A.G. 1982. 'Segmenting vacation markets: the case of the distant and near-home travellers', Journal of Travel Research, 20: 10-14.

Gatty. B. 1993. 'Worlds no.l employer', Hotel and Motel Management, p.115.

George. W.R.. Weinberger, M.G. \& Kelly, J.P. 1985. 'Consumer risk perceptions: managerial tool for the service encounter in the service encounter: managing employee/customer interaction in service businesses. In Czepiel. Solomon, M.R. \& Surprenant, C.F. (eds.). Lexington: Lexington Books, pp.83-110.

Geva, A. \& Goldman, A. 1989. 'Changes in the perception of a service during its consumption: a case of organised tours', European Journal of Marketing. 23: 44-52.

Go. F., Milne. D. \& Whittles, L.J. 1992. 'Communities as destinations: a marketing taxonomy for the effective implementation of the tourism action plan', Journal of Travel Research, 30: 31-37.

Goodrich, J.N. 1991. 'An American study of tourism marketing: impact of the Persian Gulf War'. Journal of Travel Research, 30: $37-41$.

Guseman. D.S. 1977. The perceptions of risk in consumer services a comparison with consumer products. Unpublished DBA dissertation. Colorado: University of Colorado.

Guseman, D.S. 1981. 'Risk perception and risk reduction in consumer services in marketing of services'. In Donelly, J.H. \& George. W.R., (eds.). Chicago: American Marketing Association, pp.200-204.

Hasek, G. 1991. 'Miami faces a hospitality boycott', Hotel and Motel Management, 206: 25-37.

Hawes, D.K. Taylor, D.T. \& Hampe, E.D. 1991. 'Destination marketing by states'. Journal of Travel Research, 30: 11-17.

Heath, E. \& Wall, G. 1992. Marketing tourism destinations, a strategic planning approach. New York: John Wiley and Sons.

Jacoby, J. \& Kaplan. L.. 1972. 'The components of perceived risk'. In Venkatesan. M. (ed.). Proceedings, Third Annual Convention of the Association for Consumer Research, pp.382-393.

Javalgi, R.G.. Thomas, G. \& Rao, S.R. 1992. 'U.S. pleasure travellers' perceptions of selected European destinations', European Journal of Marketing. 26: 45-64.

Kaplan, L.. Szybillo, G.L. \& Jacoby, J. 1974. 'Components of perceived risk inproduct purchase: a cross validation'. Journal of Applied Psychology. 59: 287-291.

Krippendorf. J.. 1982. 'Towards new tourism policies', Tourism Management. 3: 135-148.

Levin. R.I. \& Rubin. D.S. 1991. Statistics for management. Englewood Cliffs: Prentice Hall.

Lewıs. W. 1976. An empirical investigation of the conceptual relationship berween services and products in terms of perceived risk. Unpublished PhD Dissertation. Cincinnati: University of Cincinnati.

Lutz, R.J. \& Reilly, P.J. 1973. 'An exploration of the perceived social and performance risk on consumer information acquisition in advances in consumer research'. In Ward, S. \& Wright, P. Proceedings of the Fourth Annual Convension of the Association for Consumer Research. pp.393-405
Maheswaran, D. \& Sternthal, B. 1990. 'The effects of knowledge, motivation and type of message on ad processing and product judgements', Journal of Consumer Research, 17: 66-73.

Maslow, A.H. 1970. Motivation and personality. New York: Harper and Row.

McQueen, J. and Miller, K., 1985. 'Target market selection of tourists: a comparison of approaches', Journal of Travel Research. 24 : 26.

Miller, R.B. \& Wichern, D.W. 1977. Intermediate business statistics New York: Holt, Rinehart \& Winston.

Mowen, J.C. 1988. 'Beyond Consumer DecisionMaking', Journal of Consumer Marketing. 5: 15-25.

Nickerson, N.P. \& Ellis, G.D. 1991. 'Traveller types and activation theory: a comparison of two models', Journal of Travel Research, 29: 26-31.

Papadopoulos, S.I. 1989a. 'A conceptual tourism marketing planning model: part 1'. European Journal of Marketing, 23: 31-40.

Papadopoulos, S.I. 1989b. 'Strategy development and implementation of tourism marketing plans: part 2', European Journal of Marketing, 23: 37-47.

Pearce, D. 1987. Tourism today: a geographical analysis. Essex. England: Longman Scientific and Technical.

Perdue, R.R. \& Pitegoff, B.E. 1990. 'Methods of accountability research for destination marketing', Journal of Travel Research, 28: 45-49.

Perry, M. \& Hamm, B.C. 1969. 'Canonical analysis of the relationship between socio-economic risk and personal influence in purchase decisions', Journal of Marketing Research, 6: 351-354.

Plog, S. 1981. 'Why destination areas rise and fall in popularity in the psychology of leisure travel' . In Mayo, E.J. \& Jarvis, L.P. (eds.). Boston: CBI Publishing Company.

Roselius, E. 1971. 'Consumer rankings of risk reduction methods'. Journal of Marketing, 35: 54-60.

Satour, 1994. International strategic focus and marketing plan, 1994-1996. Pretoria.

Schewe, C.D. \& Calantone, R.J. 1978. 'Psychographic segmentation of tourists". Journal of Travel Research, 17: 14-20.

Schwaninger, M. 1984. 'Forecasting leisure and tourism', Tourism Management, 5: 250-257.

Taylor, J.W. 1974. 'The role of risk in consumer behaviour', Journal of Marketing, 38: 54-60.

Weaver, P. \& McCleary, K. 1984. 'A market segmentation study to determine the appropriate ad/model format for travel advertising'. Journal of Travel Research. 23: 12-16.

Witt, S.F., Brooke, M.Z. \& Buckley, P.J. 1991. The management of international tourism. New York: Routledge Press.

Woodside, A.G. \& Soni, P.K. 1991. 'Direct response advertising information: profiling heavy, light and non users', Journal of Travel Research, 31: 26-36.

Woodside, A.G. \& Pitts. R.E. 1976. 'Effects of consumer life styles, demographics and travel activities on foreign and domestic travel behaviour', Journal of Travel Research. 14: 13-15.

Yong, Y.W., Keng, K.A. \& Leng. T.L. 1989. 'Delphi forecast for the Singapore tourism industry: future scenario and marketing implications', European Journal of Marketing. 23: 15-26.

Yuan, S. \& McDonald, C. 1990. 'Motivational determinants of international pleasure time', Journal of Travel Research. 29: 42-44. 